\title{
Assemblages of stonefly larvae (Plecoptera) in the area of small hydrological structures, in the streams of the Kamienica Nawojowska river basin (The Beskid Sądecki)
}

\author{
ARTUR NIECHWIEJ
}

The Public Jesuit Junior High School in Mysłowice, 19 Powstańców Street, 41-400 Mysłowice, Poland, e-mail address: artursi17@wp.p1

Keywords Plecoptera, macroinvertebrates, regulation of streams, hydrological structures

Abstract The study of larval stoneflies was carried out in the years 2010-2011 in the Kamienica Nawojowska river basin. The study involved three left-bank tributaries of the Kamienica Nawojowska River: the Kryściów, Łabowczański Potok and Homerka streams, in the course of which there were present small transverse hydrological structures. In the streams, within the investigated facilities, a large taxonomic richness of stoneflies was discovered. There were no significant differences in taxonomic richness and abundance of organisms forming stonefly clusters between stations situated upstream and downstream from the small transverse hydrological structures, which do not change the volume of the flow. The shape of the clusters in the studied streams and their individual sections were not as much influenced by the presence of small transverse hydrological structures as by other conditions such as: seasonal occurrence of taxa, similar type and structure of the bottom substrate, the way in which the territory of the basin is used. Assemblages of stoneflies were not significantly depleted after regulatory works, which is confirmed by the comparison with the results of previous years.

\section{Kształtowanie się zgrupowań larw widelnic (Plecoptera) w rejonie występowania obiektów małej zabudowy hydrotechnicznej, w potokach zlewni Kamienicy Nawojowskiej (Beskid Sądecki)}

Słowa kluczowe Plecoptera, makrobezkręgowce, regulacja potoków, zabudowa hydrotechniczna

Streszczenie Badania larw widelnic prowadzono w latach 2010-2011, w zlewni Kamienicy Nawojowskiej. Objęto nimi trzy lewobrzeżne dopływy Kamienicy Nawojowskiej, potoki: Kryściów, Łabowczański i Homerkę, w biegu których obecne były obiekty małej poprzecznej zabudowy hydrotechnicznej. W potokach, w obrębie badanych obiektów stwierdzono duże bogactwo taksonomiczne widelnic. Nie wykazano znaczących różnic w bogactwie taksonomicznym i liczebności organizmów tworzących zgrupowania widelnic pomiędzy stanowiskami położonymi powyżej i poniżej małej poprzecznej zabudowy hydrotechnicznej, która nie zmienia objętości przepływu. Na kształt zgrupowań w badanych ciekach i na poszczególnych ich odcinkach większy wpływ niż obecność małej poprzecznej zabudowy hydrotechnicznej 
miały inne uwarunkowania, takie jak: sezonowość występowania taksonów, podobny rodzaj i struktura substratu dennego, charakter zagospodarowania terenu zlewni. Zgrupowania widelnic nie uległy znaczącemu zubożeniu po wykonaniu prac regulacyjnych, za czym przemawia porównanie z wynikami badań z lat wcześniejszych.

\section{Introduction}

Mountain streams are subject to a variety of hydromorphological processes. One of them is erosion: lateral, bottom and channel erosion. It is supposed to be counteracted by hydrological structures such as river bars, drop hydraulic structures and anti-debris dams (Radecki-Pawlik, 2012). However, they have an influence on a number of abiotic and biotic factors, e.g. the volume and velocity of flow, debris transport, bottom/channel shape (Wyżga et al., 2011). These changes affect in various ways particular assemblages of organisms, including benthos (Dukowska, Grzybkowska, 2007; Kukuła, Bylak, 2011) and constitute, among other things, an obstacle to the migration on aquatic organisms, cause depletion of biocenoses (Wyżga et al., 2008; Błachuta et al., 2011) and affect the drifting of invertebrates (Brittain, Eikeland, 1988).

The aim of this study was to analyze the structure of stonefly taxocoenoses (Plecoptera) which are formed in the area of small hydrological structures in the streams of the Beskid Sacdecki. It was also attempted to determine whether and to what extent the impact of these structures on the fauna of stonefly larvae is evident.

\section{Study area and methodology}

The research was conducted in the years 2010-2011 in the Kamienica Nawojowska River basin: the Kryściów, Łabowczański Potok and Homerka streams. These are streams of the fourth category and they are characterized by deeply cut valleys which are typical of the Beskids. The Kamienica Nawojowska River is a right-bank tributary of the Dunajec, into which it flows in Nowy Sącz. The length of the river is $33.079 \mathrm{~km}$ and its basin covers $237.83 \mathrm{~km}^{2}$ (according to The Regional Water Management in Krakow 2010 - RWM Krakow 2010).

The term ,facility” in order to describe the hydrological structures located in the studied streams. The following facilities were designated: one on the Kryściów stream (Nowa Wieś facility N, basin covered with forest), two on the Labowczański Potok (Łabowiec - facility L and Łabowa - facility B, basin with rural buildings and used for agricultural purposes), two on the Homerka (Homrzyska - facility H, basin covered with forest, Frycowa - facility F, basin with rural buildings and used for agricultural purposes). Three study sites were designated within each facility, in the longitudinal profile of the stream:

- site of type 1, situated approx. 20 metres upstream from the hydrological structure,

- site of type 2, situated approx. 2-3 metres downstream from the structures, depending on the size of the structure as well as the presence and the size of evorsion potholes,

- site of type 3, situated approx. 20 metres downstream from the site of type 2 . 


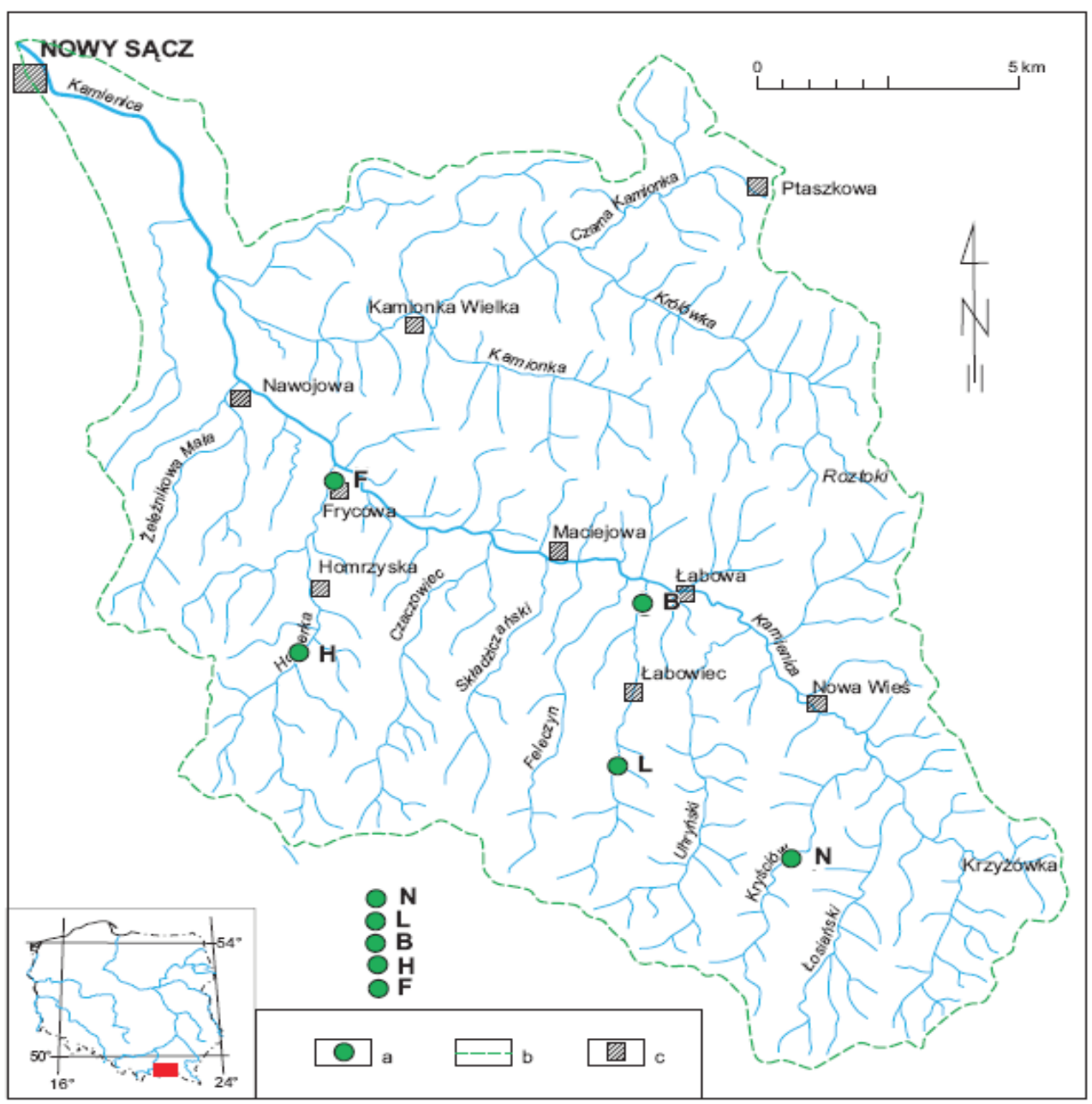

$\mathrm{a}$ - sampling sites, $\mathrm{b}$ - river basin, $\mathrm{c}$ - townes/villages.

Figure 1. Distribution of research facilities a) in the Kamienica Nawojowska basin, b) with the distribution of towns/villages, c) according to Niechwiej 2013, RWM Cracow 2010

Basic hydrological and morphological parameters of the studied streams: depth, width, water flow rate, shading of sites, coverage of the substrate by periphyton and coarse particulated organic matter (CPOM) were measured six times each year; in March, May, June, August, September and November (Bajkiewicz-Grabowska et al., 1993). Each time the physical parameters of water were measured: temperature, electrolytic conductivity, level of oxygen saturation and $\mathrm{pH}$, as well as basic chemical parameters: the concentration of ammonium, nitrates, total phosphorus and phosphates. The standardized Multi-Habitat Sampling (AQEM-STAR, 2002) method was used to collect samples of benthic fauna. Stonefly larvae were preserved in $70 \%$ ethanol and determined to the genus according (Zwick, 2004). 


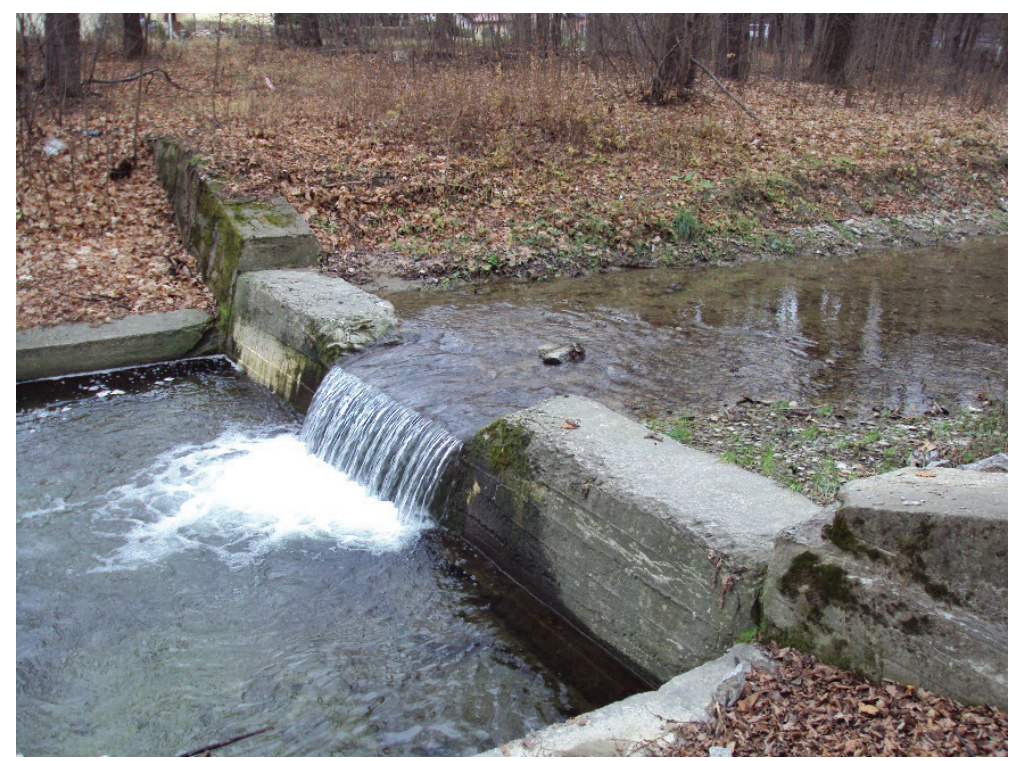

Figure 2. The typical hydrological structure in the Kamienica Nawojowska river basin

During the analysis of the results were determined: taxonomic richness, the numer of genera, the density of larvae, the structure of domination (the Szujecki occurrence stability factor, Shannon-Wiener index), faunictick similarities, the share of representatives of food guilds.

\section{Results}

Based on the measurement results, it was found out that the average depth of the surveyed streams varied in the season from $0.15 \mathrm{~m}$ (Nowa Wieś) to $0.40 \mathrm{~m}$ (Frycowa), while the average width of the flow varied from $1.5 \mathrm{~m}$ (Nowa Wieś) to $4.5 \mathrm{~m}$ (Frycowa). The flow rate of water, as determined by the floater method, ranged from $0.1 \mathrm{~m} / \mathrm{s}$ (autumn, Kryściów) to $1.1 \mathrm{~m} / \mathrm{s}$ (Homerka). The periphyton coverage of the substrate, which was determined visually, was at its lowest in March (less than 5\%), at its highest in June - to $70 \%$, whereas the coverage by CPOM was the lowest (5\%) in May and the highest in November (50\%).Within all studied objects physical and chemical parameters of water were similar and showed small fluctuations in the annual cycle, with the exception of temperature, which ranged from 2 to $12,5^{\circ} \mathrm{C}$. The degree of oxygen saturation at each site was greater than $90 \%$, the electrolytic conductivity ranged between 244 and $331 \mu \mathrm{Scm}^{-1}$, and the $\mathrm{pH}$ was within the range between 8 to 9 . The content of nitrate exceeded $1.0 \mathrm{mgNO}_{3} \mathrm{dm}^{-3}$ (1,010 only at the facility B - Łabowa), whereas the highest value of nitrogen $-0.134 \mathrm{mgNO}_{3} \mathrm{dm}^{-3}$ - was recorded at the facility F (Frycowa). The highest concentration of total phosphorus was in Homrzyska (facility $\mathrm{H}$ ) $-0,037 \mathrm{mgPdm}^{-3}$, the level of phosphates was the highest $\mathrm{n}$ Łabowa $-0.093 \mathrm{mgPO}_{4} \mathrm{dm}^{-3}$. 


\section{General characteristics of stonefly taxocoenoses}

It was discovered that in streams, within the investigated objects there is a large taxonomic richness of stoneflies. There was a total of 15 genera: two of the family Taeniopterygidae, four of the Nemouridae family, one of the Leuctridae family, two of the Perlidae and Chloroperlidae family and four belonging to the Perlodidae family.

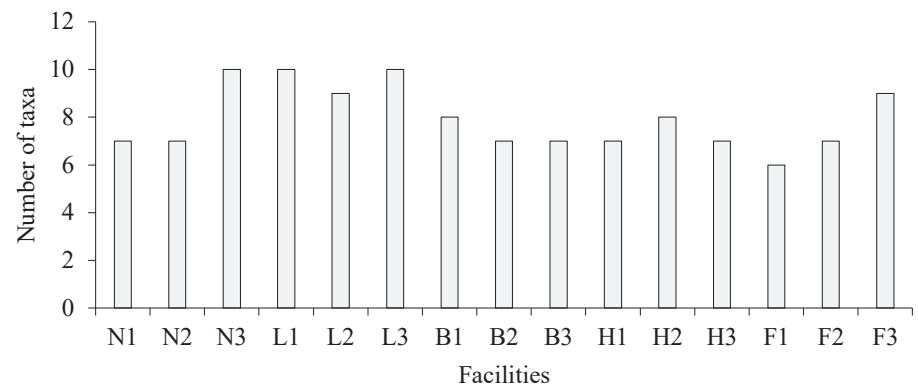

N1, N2, N3 - sites in Nowa Wieś; L1, L2, L3 - sites in Łabowiec; B1, B2, B3 - sites in Łabowa; H1, H2, H3 - sites in Homrzyska; F1, F2, F3 - sites in Frycowa

Figure 3. Taxonomic richness of stoneflies (genera) at the tested sites

The highest taxonomic richness of Plecoptera was stated at sites N3, F3 and at all sites within the facility $\mathrm{L}$ - more than 8 genera were found there. The smallest number, 6 genera, were discovered at the site F1 (Figure 3). There were no regularities in the differentiation of the number of types of stoneflies between different types of sites (types 1,2 and 3).

\section{Seasonal an spatial variation in the richness of stonefly taxocoenoses}

The number of stonefly taxa, recorded in the studied streams, fluctuated throughout the year. The highest taxonomic richness was recorded in spring and autumn (especially in November), the lowest in summer (Figure 4).

The spring, especially May, was the period when then the largest number of stonefly taxa were recorded. The presence of species of the genus Brachyptera, Rabdiopteryx, Nemurella, Xantoperla, Chloroperla, Dictyogenus, Dinocras was found primarily in the spring. During the summer and early autumn (September) the number of genera was lower, and in some cases (B1 and B3 in June, L2 in August) there were no representatives of Plecoptera at all. In the summer it was the primarily the presence of the larvae of the families Nemouridae and Lauctridae which was demonstrated and which was observed throughout the season. The occurrence of representatives of the genera Perlodes and Acrynopteryx was recorded only in this period. 
a

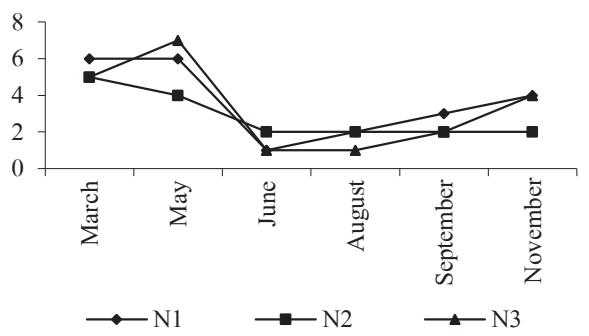

c

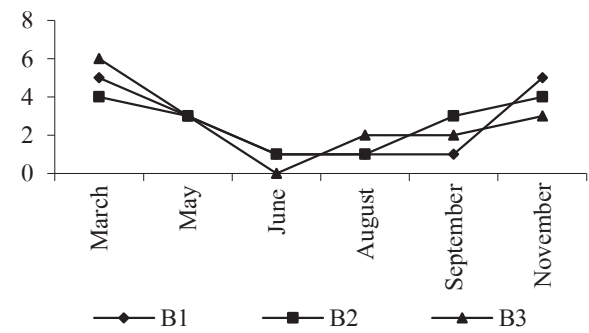

b

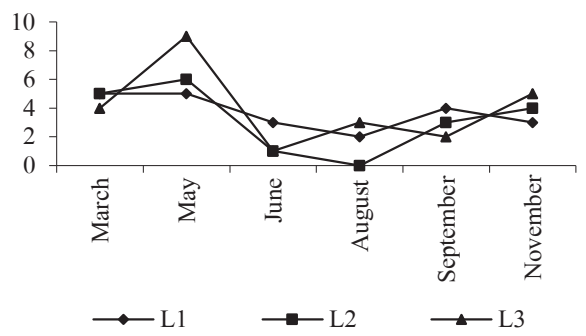

d

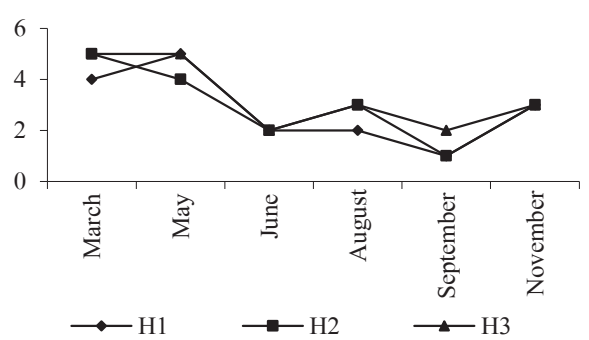

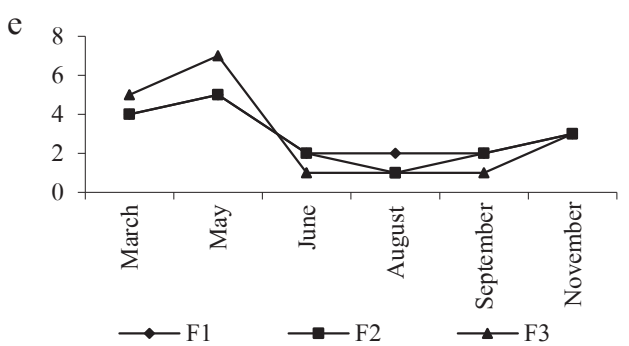

Figure 4. The number of stonefly genera observed at the studied sites in individual months

\section{Seasonal an spatial variation in the density of stonefly taxocoenoses}

The density of larvae in the studied sections of streams was subject to large fluctuations during the year. The highest density was shown in the spring, followed by a sharp decline in the summer and rise again in the autumn (Figure 5).

The highest density of larvae occurred mainly in March - to more than 600 individuals/ $\mathrm{m}^{2}$ (the site directly downstream from the structure in Labowiec - L2). In addition, the highest density was shown at sites located upstream from the structure, although apart from the facility in Frycowa, the differences were not significant compared with the sites downstream from the structure. These were especially representatives of the families Taeniopterygidae (Brachyptera sp.), Nemouridae (Nemours sp.) and Leuctridae (Table 1). The period from June to September was marked by a sharp decline in the number of stoneflies, and in some cases (eg. in June at the site B1) they were not reported at all. In this period these were mostly representatives of Protonemura sp. and Leuctra sp. that were found. November was a time of density re-growth, not as significant as 

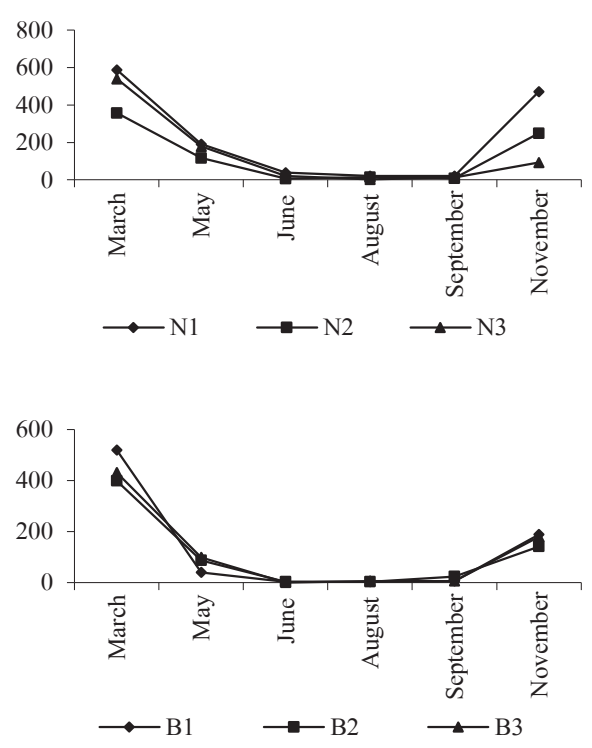

$\mathrm{b}$

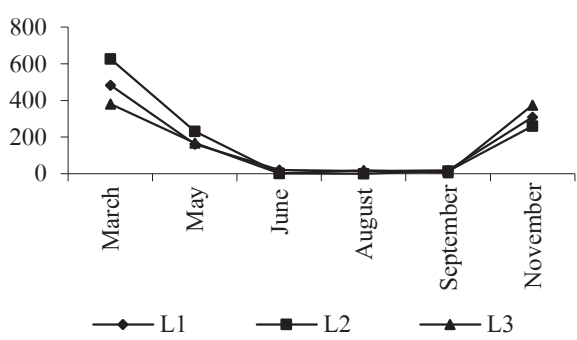

d

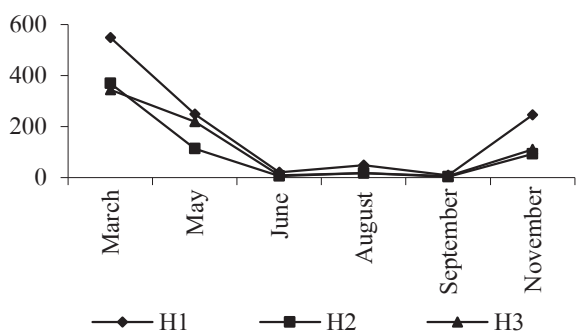

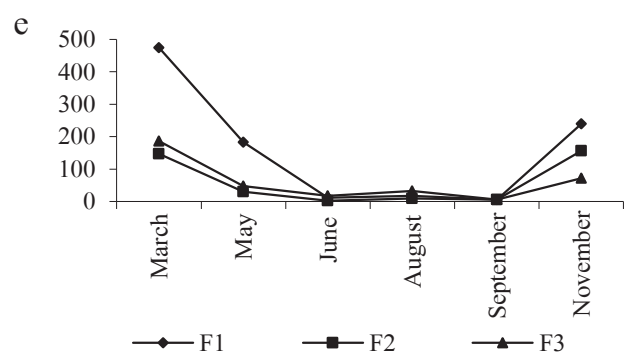

Figure 5. Changes in the density of larvae of stoneflies at different sites in individual months

Table 1. Numbers of larvae at particular posts

\begin{tabular}{|l|c|c|c|c|c|c|c|c|c|c|c|c|c|c|c|}
\hline \multicolumn{1}{|c|}{ List } & N1 & N2 & N3 & L1 & L2 & L3 & B1 & B2 & B3 & H1 & H2 & H3 & F1 & F2 & F3 \\
\hline \multicolumn{1}{|c}{} & 2 & 3 & 4 & 5 & 6 & 7 & 8 & 9 & 10 & 11 & 12 & 13 & 14 & 15 & 16 \\
\hline Rhabdiopteryx sp. & 0 & 0 & 3 & 0 & 3 & 3 & 0 & 0 & 0 & 0 & 0 & 0 & 0 & 0 & 0 \\
\hline Brachyptera sp. & 141 & 105 & 27 & 243 & 276 & 213 & 120 & 213 & 198 & 240 & 129 & 219 & 81 & 15 & 102 \\
\hline Nemoura sp. & 591 & 291 & 357 & 498 & 531 & 354 & 352 & 174 & 210 & 465 & 216 & 207 & 393 & 123 & 96 \\
\hline Protonemoura sp. & 138 & 39 & 75 & 21 & 3 & 57 & 30 & 84 & 93 & 120 & 6 & 24 & 48 & 6 & 9 \\
\hline Amphinemoura sp. & 0 & 0 & 0 & 3 & 3 & 6 & 3 & 3 & 0 & 12 & 6 & 3 & 0 & 0 & 0 \\
\hline Nemurella sp. & 3 & 3 & 3 & 0 & 6 & 0 & 0 & 0 & 0 & 0 & 0 & 0 & 0 & 3 & 0 \\
\hline Leuctra sp. & 369 & 252 & 354 & 168 & 228 & 231 & 195 & 132 & 147 & 270 & 222 & 237 & 324 & 156 & 120 \\
\hline Chloroperla sp. & 0 & 3 & 9 & 0 & 0 & 0 & 0 & 0 & 0 & 0 & 3 & 0 & 0 & 0 & 3 \\
\hline Xantoperla sp. & 0 & 0 & 0 & 0 & 0 & 3 & 0 & 0 & 0 & 0 & 0 & 0 & 0 & 0 & 0 \\
\hline Perla sp. & 0 & 0 & 3 & 3 & 6 & 6 & 9 & 3 & 6 & 3 & 12 & 3 & 6 & 3 & 9 \\
\hline
\end{tabular}




\begin{tabular}{|l|c|c|c|c|c|c|c|c|c|c|c|c|c|c|c|}
\hline \multicolumn{1}{|c|}{1} & 2 & 3 & 4 & 5 & 6 & 7 & 8 & 9 & 10 & 11 & 12 & 13 & 14 & 15 & 16 \\
\hline Dinocras $s p$. & 3 & 0 & 3 & 0 & 0 & 0 & 0 & 0 & 0 & 0 & 0 & 0 & 0 & 0 & 3 \\
\hline Perlodes $s p$. & 0 & 0 & 0 & 0 & 0 & 0 & 3 & 0 & 0 & 0 & 0 & 0 & 0 & 0 & 0 \\
\hline Dictyogenus $s p$. & 0 & 0 & 0 & 0 & 0 & 0 & 0 & 0 & 3 & 0 & 0 & 0 & 0 & 0 & 3 \\
\hline Isoperla sp. & 87 & 63 & 15 & 66 & 69 & 75 & 57 & 87 & 52 & 9 & 9 & 15 & 81 & 39 & 18 \\
\hline Acrynopteryx $s p$. & 0 & 0 & 0 & 0 & 0 & 3 & 0 & 0 & 0 & 0 & 0 & 0 & 0 & 0 & 0 \\
\hline
\end{tabular}

in early spring, although eg. at the site N1 there were 471 individuals $/ \mathrm{m}^{2}$. It was shown that the most numerous genera of larvae were Namoura, Lauctra, and Isoperla (Table 1). In November, the same as in March, the highest density of stoneflies was recorded at sites of type 1, with the exception of the facility L.

\section{The number of larvae at different sites}

\section{The structure of dominance}

Several genera clearly dominated in the studied clusters of stoneflies. The following genera can be included in the group of eudominanta (over 10\% share), or dominanta (5-10\% share) on an annual basis: Brachyptera, Nemours, Protonemura, Leuctra and Isoperla. This was evident at different sites, their types $(1,2,3)$ and in individual months (Figures 6-8).

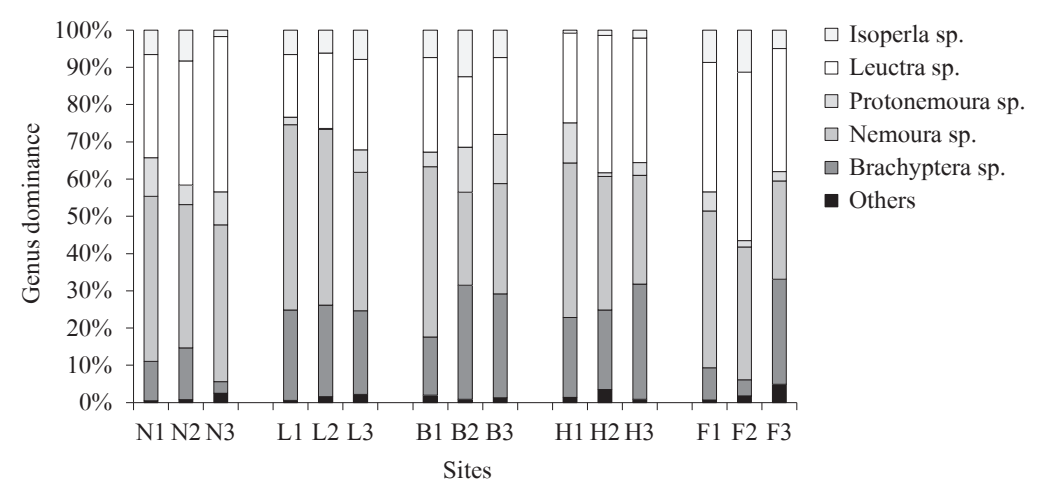

Figure 6. The share of eudominanta and dominanta at different sites during the year

All sites were clearly dominated by Nemours sp. and Leuctra sp. (Figure 6). Their share reached nearly $50 \%$ at the sites L1 (Nemours sp.) and F2 (Leuctra sp.). Representatives of Brachyptera genus had a 30\% share in all assemblages (B2 and H3), although at some sites they did not reach the status of eudominanta (N1, F1, F2). Representatives of Protonemura sp. and Isoperla $s p$. had a significantly smaller share in the assemblages. 


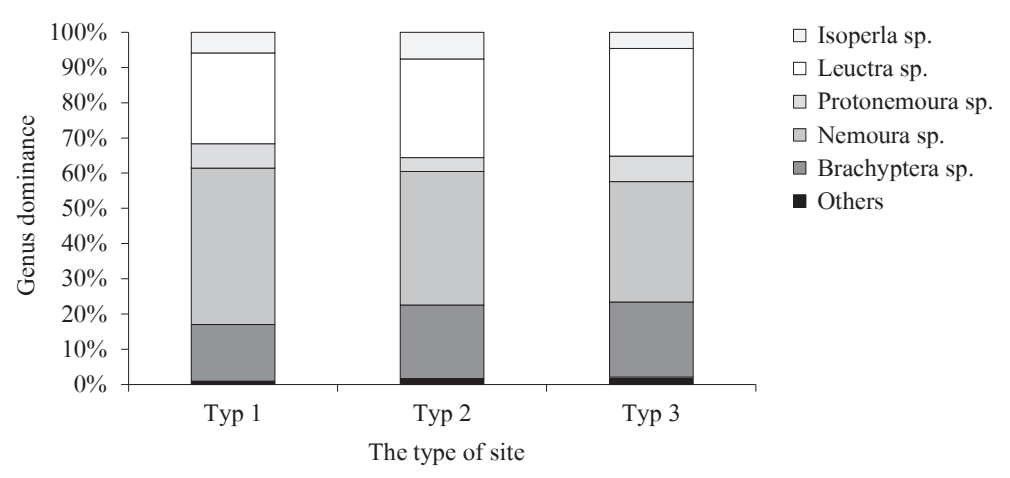

Figure 7. The share of eudominanta and dominanta at different types of sites on an annual basis

No clear trends are visible concerning the structure of dominance at individual types of sites (Figure 7). At the sites of type 1 there was the greatest share of representatives of Nemoura sp. and the smallest share of representatives of Brachyptera sp., in comparison with other types. These are not, however, significant differences.

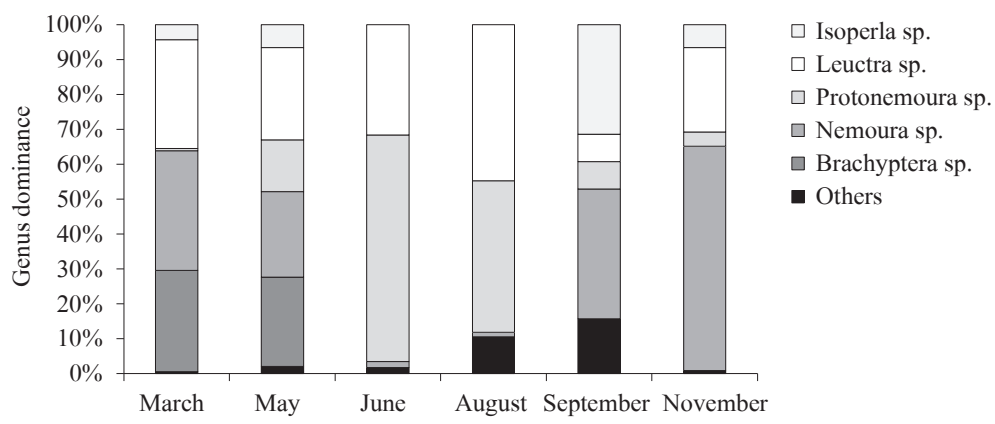

Figure 8. The share of edominanta and dominanta per year in each month

Differences in the structure of domination become apparent more clearly over time (Figure 8). The genera which dominate clearly in the spring are Brachyptera, Nemoura and Leuctra. However, they manifest themselves more visibly in early spring (March). During the summer the larvae of Leuctra sp. codominate with Protonemura sp. In September the biggest percentage is constituted by Nemoura sp. and Isoperla sp. November is a time of overwhelming dominance of Nemoura larvae (over 50\%), with a significant share of Leuctra $s p$.

The stability of occurrence of dominant taxa fluctated during the year. The Szujecki occurrence stability factor ranged from 0 to 100 (Table 2). 
Table 2. The stability factor representing the occurrence of eudominanta and dominanta

\begin{tabular}{|l|r|r|r|r|c|c|}
\cline { 2 - 7 } \multicolumn{1}{c|}{} & March & May & June & August & September & November \\
\hline Brachyptera sp. & 100 & 80 & 0 & 0 & 0 & 7 \\
\hline Nemoura sp. & 100 & 87 & 7 & 7 & 60 & 100 \\
\hline Protonemura sp. & 27 & 87 & 73 & 60 & 20 & 40 \\
\hline Leuctra $s p$. & 100 & 100 & 60 & 87 & 20 & 93 \\
\hline Isoperla sp. & 93 & 60 & 0 & 0 & 47 & 53 \\
\hline
\end{tabular}

Representatives of Brachyptera sp., Nemoura sp. and Leuctra sp. were noticed in early spring at all tested sites (Leuctra sp. also in May). During the summer no larvae of the genera Brachyptera and Isoperla were recorded. In November only representatives of Nemoura sp. were present at all sites. The smallest fluctuations in the occurrence stability were observed in case of Lauctra sp.

\section{Taxonomic diversity}

Taxonomic diversity of individual clusters of stoneflies was characterized by considerable volatility over the year, as evidenced by the values of Shannon-Wiener index (Table 3). There were months (usually the summer ones) when no specimens or only a single taxon ( 0 value in the table) were identified at part of the sites. In turn, the highest values of the index were recorded in spring months - up to 1.75 at the site L3.

Table 3. Values of te Shannon-Wiener index for stonefly clusters at tested sites

\begin{tabular}{|c|c|c|c|c|}
\hline \multirow{2}{*}{ Facilities } & \multirow{2}{*}{ Posts } & \multicolumn{3}{|c|}{ Values } \\
\hline & & $\min$. & $\max$. & average value \\
\hline \multirow{3}{*}{$\mathrm{N}$} & N1 & 0 & 1.33 & $0.97 \pm 0.49$ \\
\hline & N2 & 0.64 & 1.26 & $0.94 \pm 0.30$ \\
\hline & N3 & 0 & 1.36 & $0.67 \pm 0.58$ \\
\hline \multirow{3}{*}{$\mathrm{L}$} & L1 & 0.59 & 1.43 & $1.03 \pm 0.34$ \\
\hline & L2 & 0 & 1.48 & $0.72 \pm 0.63$ \\
\hline & L3 & 0 & 1.75 & $0.85 \pm 0.57$ \\
\hline \multirow{3}{*}{ B } & B1 & 0 & 1.28 & $0.49 \pm 0.57$ \\
\hline & B2 & 0 & 1.17 & $0.53 \pm 0.50$ \\
\hline & B3 & 0 & 1.29 & $0.63 \pm 0.43$ \\
\hline \multirow{3}{*}{$\mathrm{H}$} & $\mathrm{H} 1$ & 0 & 1.46 & $0.67 \pm 0.54$ \\
\hline & $\mathrm{H} 2$ & 0 & 1.10 & $0.73 \pm 0.39$ \\
\hline & $\mathrm{H} 3$ & 0.64 & 1.20 & $0.93 \pm 0.23$ \\
\hline \multirow{3}{*}{$\mathrm{F}$} & F1 & 0.56 & 1.35 & $0.94 \pm 0.31$ \\
\hline & F2 & 0 & 1.42 & $0.77 \pm 0.46$ \\
\hline & F3 & 0 & 1.71 & $0.54 \pm 0.73$ \\
\hline
\end{tabular}


There are no significant differences in the index values between particular watercourses. There are also no clear patterns in case of site types.

Trophic functional groups:

Various food guilds were represented by the following taxa:

Scrapers: Taeniopterygidae

Shredders: Leuctridae and Nemouridae

Predators: Chloroperlidae, Perlidae and Perlodidae.

There were no significant differences in the percentage of representatives of trophic functional groups between different sites and between different watercourses. As for the types of sites, there was a greater share of shredders at the sites of type 1 (upstream from the structures) (Figure 9).

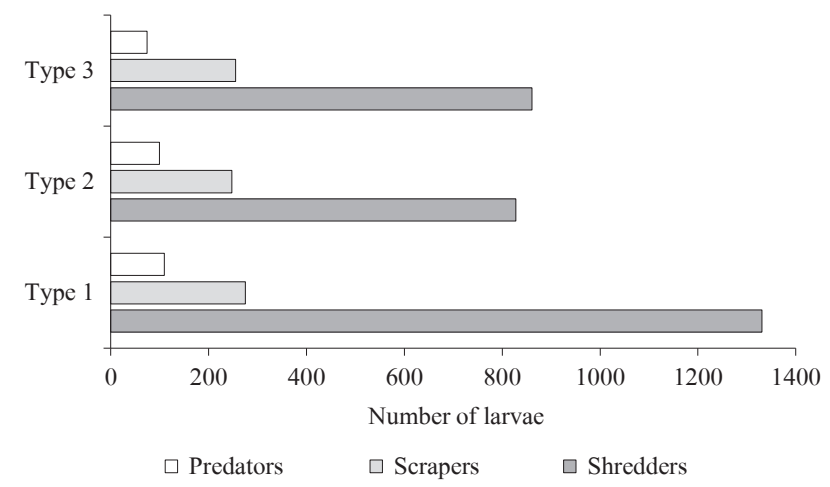

Figure 9. The share of representatives of food guilds at particular types of sites

Faunistic similarities

The tested groupings of stoneflies showed considerable faunistic similarities. This was probably due to a similar hydromorphological character of studied sections of streams and their location in a relatively small area of the same river basin. In case of sites of individual types, the distribution of faunistic similarities could be presented as Figure 10.

There is a slight difference between sites situated upstream and downstream from the hydrological structures. At the sites of the first type there were no larvae of the family Chloroperlidae or stoneflies of the genus Rhabdiopteryx (Taeniopterygidae). In addition, upstream from the structures there was a higher number of representatives of families which were present in large densities: Nemouridae, Leuctridae, Perlodidae (Table 1). 


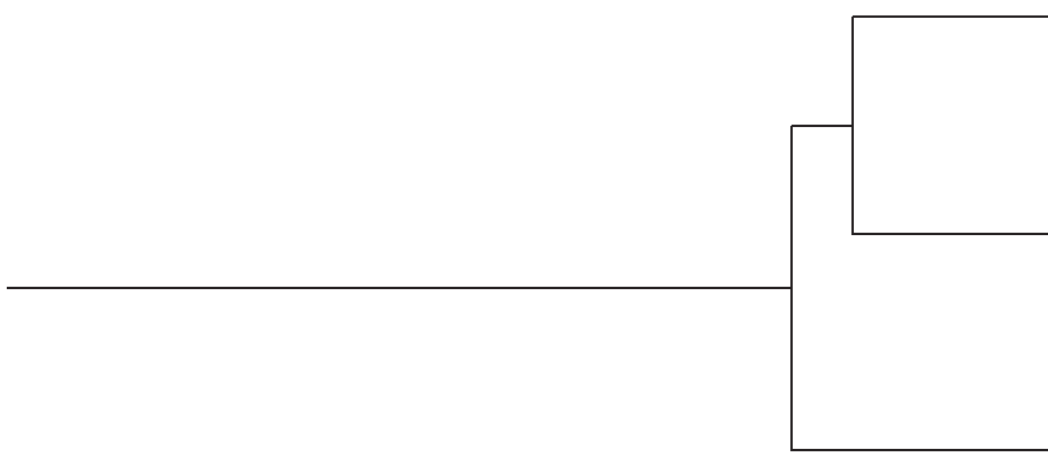

Figure 10. Diagram representing faunistic similarities by site types

\section{Discussion}

The results of the studies of stonefly fauna in the Kamienica Nawojowska river basin from the years 2010-2011 can be compared with the results of research conducted by Zaćwilichowska (1968). Zaćwilichowska collected samples in the summer and early autumn, in the period when most of the streams in Kamienica Nawojowska river basin were not yet regulated. During the comparative analysis of the results it was assumed that the sections of streams with hydrological facilities designated for research (including three sites located not far from each other) corresponded approximately to one site designated on a particular watercourse by Zaćwilichowska. Therefore, the site set out in the years 1964-1965 on the Łabowczańskim Potok corresponded to the location of the facility in Łabowiec (L), whereas the location of the site on the Homerka corresponded to the facility in Homrzyska $(\mathrm{H})$. In case of Kryściów stream the sites in both studies were designated at similar sections of the watercourse. Taxonomic richness in the tested period of summer and early autumn (the years 1964-1965 and 2010-2011) was similar, but the taxonomic structure of stonefly assemblages was different. In the years 2010-2011, especially in the Kryściów and Homerka streams, the most numerous were larvae of Protonemura $s p$. In addition, in the Homerka stream there was a large number of stoneflies of the genus Leuctra, whereas the Krysciów stream abounded in the representatives of the genus Nemoura. Also the studies conducted in the 1960's demonstrated that there were numerous representatives of Protonemura sp. at all sites, and their largest number was recorded on the Łabowczanski Potok stream. In contrast, there were no stoneflies of the genus Nemoura. Zaćwilichowska also observed a significant share of the larvae of Perlodes (Perlodes dispar accounted for $7 \%$ of the total number of benthic fauna in the Kryściów stream) in the clusters of stoneflies in the Kryściów and Homerka streams, whereas in the years 2010-2011 those stoneflies were not noticed in the area of facilities N, L and H. The present study of sections of streams in the area of selected hydrological facilities revealed the presence of representatives of 15 stonefly genera belonging to 6 families, of which the most numerous were Nemouridae, Taeniopterygidae and Leuctridae. These are taxa reported at other sites in other Beskid river basins characterized by a great taxonomic richness of stoneflies (Sowa, Szczęsny, 1970; Zasępa et al., 2006). The stoneflies observed during the previous studies of Beskid river 
basins were represented mostly by the Nemouridae and Leuctridae families and also the less numerous Perlidae and Chloroperlidae (Sowa, Szczęsny, 1970; Dratnal et al., 1979; Dratnal et al., 1982; Szczęsny, 1995). However, in the higher-lying parts of those basins there were almost no representatives (with the exception of Brachyptera sp.) of the Taenipterygidae family. This is partially confirmed by the results of research conducted in the Kamienica Nawojowska river basin in the years 2010-2011, that is large numbers of representatives of this family were recorded in spring in the studied parts of the basin which were lying below the altitude of 600 metres above sea level. The common larvae, however, were those of the Nemouridae and Leuctridae, but not of the Perlidae. The abiotic factors which most affect the taxonomic wealth of stonefly clusters in Beskid streams are: the velocity and volume of flow, the type and structure of the substrate, the nature of river basin management, as well as water temperature and its oxygenation (Hawkins et al., 1981; Donehy et al., 1999; Jowett, 2003). In the studied streams the environmental abiotic factors mentioned above were similar, favoring the presence of reophilic organisms, which resulted in a significant similarity of stonefly assemblages. There were no radical differences in taxonomic wealth between facilities (the greatest one was observed in Labowiec); some differences occurred only in the taxonomic structure of assemblages. The bottom substrate of the examined sections of streams consisted mainly of stones and gravel, as well as coarse particulate organic matter (CPOM) and deposits of sand and silt. This was conducive to a high diversity of habitats and influenced the density and distribution of benthos (Thorp, Covich, 2001). The presence of rock material with high granularity, as well as wood debris and fallen leaves create good conditions for many species (Wyżga et al., 2002). The low water temperature, alkalinity and high oxygen saturation of water contributed to the development of cryophilic species and species living in highly-oxygenated water as well as acid-sentitive ones, such as representatives of the families Leuctridae, Perlidae, Perlodidae and Chloroperlidae (Thomsen, Friberg, 2002; Bogdanowicz et al., 2007; Kozačekova et al., 2009). The taxonomic wealth of stoneflies and larval abundance are influenced by the trophic qualities of water, which are shaped, among other things, by the management of the river basin and coastal area (Kopacz, Twardy, 2006). According to Törnblom et al. (2011) stoneflies prefer watercourses of wooded river basins. Hence, the highest densities of larvae were recorded in the sections located in the wooded river basin and in midstream of the watercourses, especially in Nowa Wieś (facility N) and Łabowiec (facility L). The type of river basin cover and the position of the site in the longitutinal profile of the watercourse also influence the trophic structure of macroinvertebrate groupings (Törnblom et al., 2011). Medhurst et al. (2010) report that shredders and gatherers prevail in watercourses of wooded basins. Representatives of those trophic guilds, which were identified on the tested sections of streams, were larvae from the families Leuctridae and Nemouridae (shredders). The highest density of Leuctridae was recorded in Nowa Wieś, where there was a typically wooded river basin. Shredders also prevail in midstream of watercourses (facilitie N, L, H). The changes in the number of stonefly taxa and in the density of specimens were mainly related to their life cycles (Pastuchova, 2006; Bogdanowicz et al., 2007; Alibozek, Ganger, 2008; Błaszak et al., 2012). This was true of the Taenipterygidae family, whose representatives were recorded primarily in spring, as well as the Nemouridae family (especially Nemoura sp.) and, to a lesser extent, the Leuctridae family, but also in this case the largest numbers were recorded in spring and autumn. The velocity and volume of water flow in the stream influence the deposition of organic matter, bottom substrate structure, and thus the nutrient base of many substrate invertebrates and the microhabitat (Thorp, Covich, 2001, Small et al., 2008). The presence of transverse hydrological structure in the longitudinal profile of the watercourse influences the benthos (Fleituch, 2003; Santucci et al., 2005; Tiemanna et al., 2005; 
Vallania, Corigliano, 2007; Brown et al., 2010; Bellucci et al., 2011). The hydrological structures on the tested sections of streams did not lead to any change in the flow volume, but only in the flow velocity. Hence there is no clear difference or regularity of changes in stonefly assemblages downstream and upstream from the structures in terms of taxonomic richness or density of specimens. Aassemblages of larvae at the sites of type 2 and 3 are more similar to each other in faunistic terms than to groupings at the sites of type 1, but these are not so big differences. The similarity of clusters for three types of sites is about $75 \%$. There were also no differences in percentages of representatives of particular trophic guilds. The settlement of different types of habitats within the river channel is due, among other things, to the preferences of taxa concerning the flow velocity and drift susceptibility (Möbes-Hansen, Waringer, 1998; Armitage, Cannan, 2000). In the studied streams there were taxa preferring a fast flow and showing tolerance to high values of shear stress. These were, among other, stoneflies of the Brachyptera sp. (chosing habitats with the fastest flow), as well as Nemoura sp., Leuctra sp., Isoperla sp.

\section{Conclusions}

There were no a big differences in the taxonomic wealth and number of organisms forming stonefly clusters between sites situated upstream and downstream small transverse hydrological structures, which do not change the flow volume. The shape of assemblages in the investigated streams and on their particular sections was more influenced by other factors, e.g. the seasonality of taxa, the similar type and structure of the bottom substrate, the nature of river basin development. Stonefly assemblages were not significantly impoverished after regulatory works, which can be supported by the comparison with reserach from previous years.

\section{Acknowledgements}

I would like to express my deep gratitude for their help to Izabela Czerniawska-Kusza PhD Hab. and Grzegorz Tończyk PhD. I would also like to thank Ms Katarzyna Niechwiej.

\section{Bibliography}

Alibozek, J., Ganger, M. (2008). Temporal Changes in Stream Insect Abundance in Northwestern Massachusetts. Journal of Freshwater Ecology, 4 (23), 673-676.

AQEM-STAR (2002). Manual for the application of the AQEM method. A comprehensive method to assess European streams using benthicmacroinvertebrates, developed for the purpose of the Water Framework Directive. Version 1.0, 1-89.

Armitage, P.D., Cannan, C.E. (2000). Annual changes in summer patterns of mesohabitat distribution and associated macroinvertebrate assemblages. Hydrol. Process., 14, 3161-3179.

Bajkiewicz-Grabowska, E., Magnuszewski, A., Mikulski, Z. (1993). Hydrometria. Warszawa: Wydawnictwo Naukowe PWN.

Bellucci, C.J., Becker, M., Beauchene, M. (2011). Effects of small dams on aquatic biota in two Connecticut streams. Connecticut Department of Energy and Environmental Protection. Hartford, CT 06106.

Błachuta, J., Wiśniewolski, W., Zgrabczyński, J., Domagała, J. (2011). Ocena potrzeb i priorytetów udrażniania ciagłości morfologicznej rzek na obszarach dorzeczy w kontekście osiagnięcia dobrego stanu i potencjału ekologicznego JCWP. Poznań: RZWG. 
Błaszak, C. (ed.) (2012). Zoologia. T. II, cz. II. Warszawa: Wydawnictwo Naukowe PWN.

Bogdanowicz, W., Chudzicka, E., Pilipiuk, I., Skibińska, E. (2007). Fauna Polski. Charakterystyka i wykaz gatunków. T. II. Warszawa: Muzeum i Instytut Zoologii PAN..

Brittain, J.E., Eikeland, T.J. (1988). Interbrate drift - a review. Hydrobiologia, 166, 77-93.

Brown, P.D., Wooster, D., Johnson, S.L., Debano, S.J. (2010). Effects of water withdrawals on macroinvertebrate emergence: unexpected results for three holometabolous species. River Res. Applic., 28, $347-358$.

Dratnal, E., Sowa, R., Szczęsny, B. (1979). Zgrupowania bezkręgowców bentosowych Dunajca na odcinku Harklowa-Sromowce Niżne. Ochrona Przyrody, 42, 183-215.

Dratnal, E., Sowa, R., Szczęsny, B. (1982). Zgrupowania zwierząt bezkręgowych w wodach Pienin. In: K. Zarzycki (ed.), Przyroda Pienin w obliczu zmian (pp. 379-399). Warszawa: Wydawnictwo PWN.

Dukowska, M., Grzybkowska, M. (2007). Reakcja bentofauny na pietrzenie. Nauka Przyroda Technologie, $l(2), 16$.

Fleituch, T. (2003). Structure and Functional Organization of Benthic Invertebrates in a Regulated Stream. Internat. Rev. Hydrobiol., 3-4 (88), 332-344.

Hawkins, Ch.P., Sedell, J.R. (1981). Longitudinal and Seasonal Changes in Functional Organization of Macroinvertebrate Communities in Four Oregon Streams. Ecology, 2 (62), 387-397.

Jowett, I.G. (2003). Hydraulic constraints on habitat suitability for benthic invertebrates in gravel-bed rivers. River Res. Applic., 19, 495-507.

Kopacz, M., Twardy, S. (2006). Zmiany użytkowania ziemi w zlewni górnego Dunajca w aspekcie wybranych parametrów jakościowych wód powierzchniowych. Woda - Środowisko - Obszary Wiejskie, 6/2 (18), 191-202.

Kozačekova, Z., Tierno de Figueroa, J.M., Lopez-Rodriguez, M.J., Beracko, P., Derka, T. (2009). Internat. Rev. Hydrobiol., 1 (94), 57-66.

Kukuła, K., Bylak, A. (2011). Wpływ czynników antropogenicznych na faunę karpackich dopływów Wisły. Roczniki Bieszczadzkie, 19, 207-222.

Medhurst, R.B., Wipfli, M.S., Binckley, Ch., Polivka, K., Hessburg, P.F., Salter, R.B. (2010). Headwater streams and forest management: Does ecoregional context influence logging effects on benthic communities? Hydrobiologia, 641, 71-83.

Möbes-Hansen, B., Waringer, J.A. (1998). The Influence of Hydraulic Stress on Microdistribution Patterns of Zoobenthos in a Sandstone Brook (Weidlingbach, Lower Austria). Internat. Rev. Hydrobiol., 5-6 (83), 381-396.

Niechwiej, A. (2013). Wpływ poprzecznej zabudowy hydrotechnicznej na zgrupowania chruścików (Trichoptera) w dopływach Kamienicy Nawojowskiej (Beskid Sądecki). Chrońmy Przyr. Ojcz., 6 (69), 483-493.

Pastuchová, Z. (2006). Macroinvertebrate assemblages in conditions of low-discharge streams of the Cerová vrchovina highland in Slovakia. Limnologica, 36, 241-250.

Radecki-Pawlik, A. (2012). Budowle hydrotechniczne w korytach rzek górskich. In: K. Krzemień (ed.), Struktura koryt rzek i potoków (studium metodyczne) (pp. 55-77). Kraków: Instytut Geografii i Gospodarki Przestrzennej UJ.

Regionalny Zarząd Gospodarki Wodnej w Krakowie (2010). Wykaz cieków w zlewni rzeki Kamienicy wg MPHP v. 09-2010.

Santucci, Jr.V.,J., Gephard, S.R., Pascitelli, S.M. (2005). Effects of Multiple Low-Head Dams on Fish, Macroinvertebrates, Habitat, and Water Quality in the Fox River, Illinois. North American Journal of Fisheries Management, 25, 975-992. 
Small, M.J., Doyle, M.W., Fuller, R.L., Manners, R.B. (2008). Hydrologic versus geomorphic limitation on CPOM storage in stream ecosystems. Freshwater Biology, 53, 1618-1631.

Sowa, R., Szczęsny, B. (1970). Widelnice (Plecoptera) i chruściki (Trichoptera) Babiej Góry. Ochrona Przyrody, 35, 221-268.

Szczęsny, B. (ed.). 1995. Degradacja fauny bezkręgowców bentosowych Dunajca w rejonie Pienińskiego Parku Narodowego. Ochrona Przyrody, 52, 207-224.

Thomsen, A.G., Friberg, N. (2002). Growth and emergence of the stonefly Leuctra nigra in coniferous forest streams with contrasting pH. Freshwater Biology, 47, 1159-1172.

Thorp, J.H., Covich, A.P. (eds.) (2001). Ecology and classification of North American freshwater invertebrates. Academic Press.

Tiemann, J.S., Gillette, D.P., Wildhaber, M.L., Edds, D.R. (2005). Effects of Lowhead Dams on the Ephemeropterans, Plecopterans, and Trichopterans Group in a North American River. Journal of Freshwater Ecology, 3 (20), 519-525.

Törnblom, J., Angelstam, P., Degerman, E., Henrikson, L., Edman, T., Temnerud, J. (2011). Catchment land cover as a proxy for macroinvertebrate assemblage structure in Carpathian Mountain streams. Hydrobiologia, 673, 153-168.

Wyżga, B., Kaczka, R.J., Zawiejska, J. (2002). Gruby rumosz drzewny w ciekach górskich - formy występowania, warunki depozycji i znaczenie środowiskowe. Folia Geographica, Series Geographica-Physica, 33-34, 117-138.

Wyżga, B., Bojarski, A., Jeleński, J., Zalewski, J. (2008). Zagrożenia dla zrównoważonego stanu środowiska cieków karpackich i proponowane działania zaradcze. In: B. Wyżga (ed.), Stan środowiska rzek południowej Polski i możliwości jego poprawy - wybrane aspekty (pp. 121-133). Kraków: Instytut Ochrony Przyrody PAN.

Wyżga, B., Oglęcki, P., Radecki-Pawlik, A., Zawiejska, J. (2011). Diversity of Macroinvertebrate Communities as a Reflection of Habitat Heterogeneity in a Mountain River Subjected to Variable Human Impacts. In: A. Simmon, S.J. Bennet, J.M. Castro (eds.), Stream Restoration in Dynamic Fluvial Systems: Scientific Approaches, Analyses, and Tools (pp. 189-207). Washington: American Geophysical Union.

Vallania, A., Corigliano, M. (2007). The effect of regulation caused by a dam on the distribution of the functional feeding groups of the benthos in the sub basin of the Grande River (San Luis, Argentina). Environ. Monit. Assess., 124, 201-209.

Zaćwilichowska, K. (1968). Bootom fauna in the basin of the river Kamienica Nawojowska. Acta Hydrobiol., 10, 319-341.

Zasępa, P., Kłonowska-Olejnik, M., Radecki-Pawlik, A. (2006). Wpływ wybranych zmian abiotycznych w rejonie łachy żwirowej potoku górskiego na mikrosiedliska makrobezkęgowców dennych. Infrastruktura i Ekologia Terenów Wiejskich, 2 (4), 221-232.

Zwick, P. (2004). Key to the West Palaearctic genera of stoneflies (Plecoptera) in the larval stage. Limnologica, 34, 315-348.

Cite as: Niechwiej, A. (2017). Assemblages of stonefly larvae (Plecoptera) in the area of small hydrological structures, in the streams of the Kamienica Nawojowska river basin (The Beskid Sądecki). Acta Biologica, 24, 73-88. DOI: 10.18276/ab.2017.24-08. 